\title{
Identidade e liderança na prática do ensino
}

\section{Identity and leadership in teaching practice}

\section{Identidad y liderazgo en la práctica docente}

Thiago Galbiatti Vespa

Universidade de São Paulo (Brasil)

PALMER, Parker J. A coragem de ensinar: a vocação, as dificuldades e o potencial transformador de um professor. São Paulo: Editora Da Boa Prosa, 2012.

Parker J. Palmer produziu um excelente livro ao abordar as dores e satisfações de ser um professor. Embora tenha sido inicialmente escrito com foco em professores, o público que pode se beneficiar de seu conteúdo é bem abrangente. Ao folhear cada página desta obra, líderes em geral, pensadores, escritores, e qualquer um que tenha interesse em fazer do mundo um lugar melhor, encontram sugestões que os levam a viajar em seu próprio interior e a se descobrir.

motivo dessa amplitude de leitores é que bons professores possuem características comuns às qualificações de vários profissionais. $\bigcirc$ próprio autor ressalta a abrangência de profissões e extensão geográfica que a obra atinge no prefácio dessa edição. Para mensurar o impacto do livro, pode-se comprovar sua influência, inclusive, na área médica. $\bigcirc$ Conselho de Acreditação para Educação Médica de Pós-Graduação dos Estados Unidos, no original em inglês: Accreditation Council for Graduate Medical Education (ACGME), criou o prêmio "Parker J. Palmer: A coragem de ensinar". Essa honraria é concedida anualmente aos diretores de dez programas de residência que demonstram o profissionalismo centrado no paciente na educação médica.

A primeira edição do livro é de 1997, em 2007, foi relançado e atualizado pela John Willey \& Sons, Inc. A versão em língua portuguesa dessa edição comemorativa de dez anos do livro foi produzida em 2012 pela Editora Da Boa Prosa. Com o título original em inglês "The courage to teach", tem tradução de Aline Storto Pereira.

autor se concentra nos obstáculos internos encontrados no ensino e como é possível superá-los sem desconsiderar as condições exteriores. A busca 
pelo autoconhecimento e a introspecção é uma constância no livro. Com isso, o autor guia o leitor em busca de motivações e estimula a iniciativa e a confiança. A estratégia abordada é ressaltar a subjetividade do ser, os aspectos intensos da emoção e como direcioná-los para a busca da excelência.

A introdução abrange maneiras de como encontrar dentro de si o valor de ensinar. $\bigcirc$ livro se divide em sete seções, a começar pelas definições de identidade e integridade, a alma do nosso ser. $\bigcirc$ autor descreve a importância das técnicas, mas sua total insuficiência. Isso se torna evidente ao entendermos que não é a habilidade de trabalhar com uma faca que distingue um assassino de um cirurgião, que cura as pessoas, mas sim o coração. A boa prática de ensino vem, portanto, da integridade e identidade do professor. Por isso, o foco é educar o coração e não as técnicas. $\bigcirc$ livro transcorre na definição da integridade daquilo que é intrínseco à personalidade considerando sua relação com a identidade. Apesar da definição, o autor reconhece que esses conceitos não podem ser completamente conhecidos por ninguém. Esses princípios são explicados por histórias, o que facilita a compreensão geral e torna a leitura bem agradável.

Além de ressaltar os pontos altos e baixos do cotidiano do professor, vai ao âmago da formação da identidade e categoriza os degraus que nos levam à constituição do nosso caráter, seja na identificação dos mentores que nos inspiraram, seja nas disciplinas que nos escolheram. Com isso, se aprofunda na intimidade de cada um e disseca os problemas comuns da docência.

Em continuidade, aborda o tópico do medo. $\bigcirc$ autor ressalta a limitação do medo que incapacita o professor e seus alunos de estabelecerem conexões. No núcleo do questionamento do medo, descreve como as emoções podem paralisar ou libertar a mente. As emoções caminham com o intelecto e é necessário abrir as mentes dos alunos para despertar seus sentimentos. Um mundo de paradoxos na educação é desvelado: mentes que não sabem sentir e corações que não sabem pensar; a separação entre teoria e prática; professores que falam, mas não ouvem e alunos que ouvem, mas não falam.

$\bigcirc$ leitor é guiado pelas emoções e subjetividade entremeadas com o diálogo entre seus pares que compartilham o conhecimento e sentimentos em comunidade. Palmer conclui com a sugestão de uma reforma educacional a partir de um movimento social para revitalizar a educação. Esse corolário se baseia em um conjunto de etapas, que começa com o indivíduo isolado, passa 
pela formação de comunidades que possuem pessoas com visão compartithada, definidas como comunidades de harmonia, e termina em um movimento de mudanças no sistema institucional. As comunidades de harmonia são locais no qual não apenas se contribui, mas que se pode contar com o apoio, independentemente da condição em que se esteja. Essas comunidades não nos definem, mas nos ajudam a recuperar paixões perdidas. São descritas pelo autor como fundamentais "para a reforma educacional, mas criá-las se torna difícil devido ao caráter privado da vida acadêmica". Palmer apoia a declaração pública e visível de nossos valores em busca de aliados na formação de comunidades de harmonia.

Além do conhecimento que o livro promove, essa edição comemorativa conta com um posfácio e uma descrição da carreira do autor. Outro ponto muito positivo é que cada capítulo possui uma citação instigadora que funciona como prelúdio motivador para o conteúdo que se segue. Em resumo, o livro ressalta a importância do autoconhecimento, pois você ensina o que você é. A questão central é: "quem é o eu que ensina?", sem focar no "quê", "comos" e "por quês", mas na subjetividade do educador. $\bigcirc$ autor ressalta que o questionamento é ensino, ao invés de fala, e aborda o conceito de espaços intelectuais, emocionais e espirituais.

É um livro de muita relevância em todas as épocas, principalmente para a cultura ocidental, na qual cada profissional acaba buscando a objetividade em metas e esquece-se da influência da subjetividade em seu ser. É necessário coragem para essa busca. Líderes em todas as áreas precisam entender a vocação, as dificuldades e o potencial transformador de suas influências na vida das pessoas ao seu redor. A leitura é agradável, com uma ideia interessante e original. A falta de referências adicionais e diagramas explicativos são pontos que poderiam ser melhor desenvolvidos na obra. Apesar disso, não é necessário conhecimento prévio por parte do leitor, é um livro que pode ser aplicado a um inúmero conjunto de áreas. A tradução é correta, o conhecimento fornecido é bem estruturado e segue uma ordem lógica das ideias. A presença de histórias para ilustrar os conceitos é uma estratégia acertada para a compreensão por qualquer um que se aventure nessa leitura. Provavelmente, essa abordagem advém da experiência do autor com mais de três décadas como professor.

cerne teórico para aplicação prática do livro é a transformação reflexiva do profissional e não há como permanecer o mesmo depois de sua 
leitura. Os conceitos centrais são a educação do coração e a paixão pelo ensino. A definição do ser não é composta pelos seus sucessos e falhas, mas sim por seus valores e sua integridade. A busca pelo que nos faz sentir vivos é o começo da resposta que o livro nos leva a perscrutar. Com isso, é necessário buscar essa jornada interior: ser um líder e conhecer a si mesmo como professor para que se possa trazer a verdadeira luz para as pessoas ao seu redor.

Thiago Galbiatti Vespa

Doutorando em Liderança pela Andrews University (EUA) EDeTEC - Grupo de Pesquisa Educação e Tecnologia Mestre em Ciências - Universidade de São Paulo (Brasil) Universidade Estadual Paulista "Júlio de Mesquita Filho" (Brasil) Orcid id: https:/ / orcid.org/0000-0003-2193-2950 E-mail: thiagogv@gmail.com

Recebido 4 jun. 2020 Aceito 11 jun. 2020 